\title{
В РОССИИ
}

\section{ЗАПУЩЕНА ПЕРВАЯ}

региональная магистральная

\section{квантовая сеть}

А.Иванов, президент АО "СMАРТС" / smarts@smarts.ru

DOI: $10.22184 / 2070-8963.2021 .95 .3 .22 .23$

Первая в России региональная магистральная квантовая сеть, связавшая цОДы в трех городах СамарскоТольяттинской городской агломерации, построена и успешно введена в эксплуатацию специалистами AO "СМАРТС" (г. Самара). Надежное шифрование передаваемого по ВОЛС трафика обеспечивается устройствами рассылки квантовых ключей одного из предприятий группы компаний "СМАРТС".

Все больше компаний заявляют об успехах в разработке квантовых компьютеров, чей вычислительный ресурс будет на порядок превышать все существующие вычислительные системы. Это означает, что в ближайшие годы все известные криптографические системы, в основе которых лежат математические алгоритмы шифрования, окажутся бесполезными. Даже самую сложную из них можно будет взломать, используя мощные квантовые суперкомпьютеры.

Передача данных по существующим волоконнооптическим линиям связи (ВОЛС) легко подвержена атакам класса "человек посередине" - вид атаки в криптографии, когда "нарушитель" способен не только перехватывать информацию, которой обмениваются отправитель и получатель, но и изменять ее, сохраняя в обеих жертвах уверенность в том, что на линии они вдвоем и данные остались нетронутыми.

Предупредить подобные угрозы возможно путем внедрения квантовых коммуникационных систем, которые гарантируют абсолютную неуязвимость ВОЛС для атак. Квантовая криптография не зависит от вычислительных мощностей "нарушителя"! В системе квантовых коммуникаций на защиту данных встают законы физики: носителями информации здесь выступают одиночные фотоны, которые необратимо изменяются при любой попытке перехвата сигнала. Таким образом, пользователь мгновенно узнает о вторжении в канал связи. Путем измерения состояний фотонов получателем и сравнений их с данными отправителя формируется закрытый ключ шифрования, известный только им.

Технология защищенной квантовой коммуникации позволит банковским структурам, госорганам и спецслужбам, использующим для передачи данных в неконтролируемой зоне выделенные оптические волокна (ОВ), обмениваться информацией с нулевой вероятностью несанкционированного доступа.

ООО "СМАРТС-Кванттелеком" (дочерняя компания ГК "СМАРТС") разработало совместно с Университетом ИТМО и производит квантовую систему защиты информации - устройство рассылки квантовых криптографических ключей, которое относится к новейшему поколению систем безопасной передачи данных. Система способна обеспечить передачу по ОВ квантовых сигналов на расстояние до 200 км. Это первое отечествен ${ }^{-}$ ное решение, которое по совокупности характеристик способно конкурировать с лучшими мировыми разработками.

С использованием упомянутого устройства рассылки квантовых ключей на базе вновь построенных ГК "СМАРТС" ВОЛС создана первая в стране региональная сеть связи на основе квантовых коммуникаций, которая введена в эксплуатацию в марте 2021 года. Она объединила в единую систему ЦОДы в Самаре, Тольятти 
и Сызрани. Новая сеть предназначена для передачи конфиденциальной информации. Скорость передачи защищенного трафика составляет 10 Гбит/с, открытого трафика - 4×10 Гбит/с. Ее пользователями будут компании банковской и финансовой сферы, ЦОДы, правительственные и муниципальные организации, корпоративные заказчики, операторы связи.

Отметим, что ВОЛС, связавшие три упомянутых города, построены вдоль автодороги M5 на основе запатентованной экономичной технологии строительства автодорожных телекоммуникационных сетей ГК "СМАРТС": путем разработки в обочине дороги мини-траншеи с укладкой в нее пакета микротрубок, в которые по мере необходимости прокладываются оптические отечественные кабели с волокном российского производства ООО "Оптиковолоконные системы" (г. Саранск). В Самарской области компанией вдоль автодорог построена разветвленная телекоммуникационная волоконно-оптическая инфраструктура общей протяженностью уже около 1500 км.

Реализация проекта в Самарской области представляет собой важный шаг на пути к выполнению целевых показателей дорожной карты развития сКЦ "Квантовые технологии" по направлению квантовых коммуникаций.

Следует добавить, что продвигаемая "СМАРТС" технология передачи квантовых ключей может в качестве передающей среды использовать не только оптическое волокно, но и атмосферную оптическую линию связи (АОЛС). В январе 2021 года на технологической площадке в Самаре были успешно проведены комплексные испытания по передаче квантовых ключей шифрования по атмосферному каналу с использованием новой версии оборудования разработки компании "СМАРТС-Кванттелеком".

Работа выполнялась в рамках предложений по улучшению технических характеристик приемо-передающего оборудования, сформированных в ходе проведения приемочных испытаний годом ранее, - в ходе реализации проекта "Создание новых технологических компонентов систем управления географически

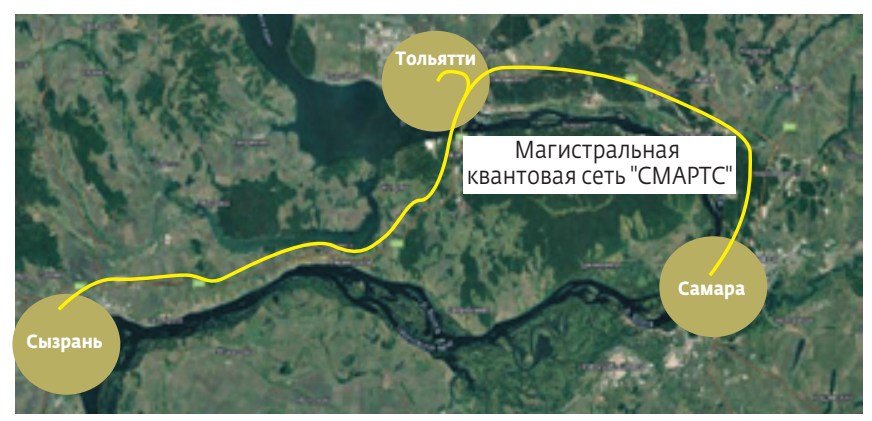

распределенными ЦОДами, включая виртуализацию ресурсов с использованием квантовых технологий для защиты линий связи" АО "СМАРТС" совместно с Университетом ИТМО при поддержке Минобрнауки России.

В ходе испытаний была продемонстрирована уникальная гибридная технология передачи квантовых ключей, которая может в качестве передающей среды использовать одновременно ОВ и АОЛС. Ключевая информация передавалась на первом участке по оптоволокну, которое продолжалось атмосферным оптическим каналом длиной порядка 30-40 м.

Подчеркнем, что при одновременном использовании лазерного канала и одномодового ОВ требуется очень высокая точность взаимного позиционирования передатчика и приемника. Испытания подтвердили, что в новой версии оборудования необходимые показатели были достигнуты: в ходе доработки системы точность повысилась в 150 раз. Такие характеристики позволят использовать данное оборудование для предоставления коммерческих услуг.

Актуальность этой разработки обусловлена необходимостью взаимодействия инфраструктуры умной дороги с подвижными объектами по каналам связи, защищенным квантовой криптографией. Уже к 2024 году на автомагистралях и железных дорогах должны появиться беспилотные транспортные средства, связь с которыми возможно будет защитить преимущественно квантовыми коммуникациями от этого будет зависеть безопасность людей.

\section{УСТРОЙСТВО РАССЫЛКИ КВАНТОВЫХ КРИПТОГРАФИЧЕСКИХ КЛЮЧЕЙ}

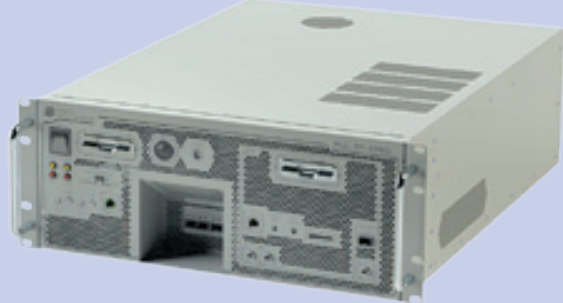

- Скорость генерации квантового ключа: > 10 кбит/с (1 км)

- Частота обновления ключа до 100 раз в секунду

- Предельные потери в оптическом канале: 40 дБ (230 км)

- Спектральный диапазон С (1530. 1565 нм)

- Коэффициент квантовых ошибок (QBER): $<5 \%$
- Тип волокна: SMF-28е или аналогичное

- Поддержка AES, DES, ГОСТ 28147-89

- Скорость передачи данных 10 Гбит/с

- Поддержка протоколов TCP/IP, UDP

- Интерфейс подключения: fc/apc

- Частота импульсов: 100 МГц

- Маршрутизация L2/L3

- Габариты устройства: 3U, 19" 